\title{
WEIGHT LOSS AND MORPHOMETRIC STUDY OF INTESTINAL MUCOSA IN RATS AFTER MASSIVE INTESTINAL RESECTION. INFLUENCE OF A GLUTAMINE-ENRICHED DIET
}

Sidney Resende Ribeiro, Paulo Engler Pinto Júnior, Ariney Costa de Miranda, Sansom Henrique Bromberg, Fábio Pinatel Lopasso and Kiyoshi Irya

RIBEIRO SR et al. Weight loss and morphometric study of intestinal mucosa in rats after massive intestinal resection. Influence of a glutamine-enriched diet. Rev. Hosp. Clin. Fac. Med. S. Paulo 59(6):349-356, 2004.

Short-bowel syndrome is responsible for significant metabolic alterations that compromise nutritional status. Glutamine is considered an essential nutrient for enterocytes, so beneficial effects from supplementation of the diet with glutamine are hypothesized.

PURPOSE: In this study, the effect of a diet enriched with glutamine was evaluated in rats undergoing extensive small bowel resection, with analysis of postoperative weight loss and intestinal morphometrics of villi height, crypt depth, and thickness of the duodenal and remnant jejunal mucosa.

METHODS: Three groups of male Wistar rats were established receiving the following diets: with glutamine, without glutamine, and the standard diet of laboratory ration. All animals underwent an extensive small bowel resection, including the ileocecal valve, leaving a remnant jejunum of only $25 \mathrm{~cm}$ from the pylorus that was anastomosed lateral-laterally to the ascendant colon. The animals were weighed at the beginning and end of the experiment ( $20^{\text {th }}$ postoperative day). Then they were killed and the remnant intestine was removed. Fragments of duodenal and jejunal mucosa were collected from the remnant intestine and submitted to histopathologic exam. The morphometric study of the intestinal mucosa was accomplished using a digital system (KS 300) connected to an optic microscope. Morphometrics included villi height, crypt depth, and the total thickness of intestinal mucosa.

RESULTS: The weight loss comparison among the 3 groups showed no significant loss difference. The morphometric studies showed significantly taller duodenal villi in the glutamine group in comparison to the without glutamine group, but not different from the standard diet group. The measurements obtained comparing the 3 groups for villi height, crypt depth, and thickness of the remnant jejunum mucosa were greater in the glutamine-enriched diet group than for the withoutglutamine diet group, though not significantly different from with standard-diet group.

CONCLUSIONS: In rats with experimentally produced short-bowel syndrome, glutamine-enrichment of an isonitrogenous test diet was associated with an improved adaptation response by the intestinal mucosa but not reduced weight loss. However, the adaptation response in the group receiving the glutamine-enriched diet was not improved over that for the group fed regular chow.

KEYWORDS: Glutamine. Short-bowel syndrome. Intestinal mucosa.

Short-bowel syndrome (SBS) occurs after massive intestinal resection in the treatment of inflammatory diseases, volvulus, abdominal trauma, mesenteric ischemia, and other afflictions. It causes significant metabolic alterations of lipids, ${ }^{1}$ insulin, fatty acids, hepatic glycogen, and glycemia ${ }^{2}$ that in the long term influence the prognosis of the patient.$^{3}$ In these pa-

From the "Instituto de Assistência ao Servidor Público Estadual (IAMSPE)” and Clinical Investigation Laboratory, Faculty of Medicine, University of São Paulo - São Paulo/SP, Brazil. E-mail:pengler@terra.com.br

Received for publication on April 12, 2004. Accepted for publication on July 07, 2004. tients, the intestinal absorption of nutrients depends on many factors, such as the extent of the resected segment; the presence of ileocecal valve; the function of the colon, stomach, pancreas, liver, and remnant small bowel; and adaptive changes of the gastrointestinal tract. ${ }^{4}$ 
Glutamine comprises almost $20 \%$ of the amino acids found in the blood stream, almost twice as much as alanine. ${ }^{5}$ Its plasma concentration reduces during catabolic conditions. ${ }^{6}$ Classified as a nonessential amino acid because of being synthesized in various tissues from glutamate, it is considered a primary nutrient required by the enterocytes for their growth and energetic substrate. $7,8,9,10,11$ Glutamine also plays an important role in nitrogen transport among tissues, ${ }^{12}$ regulating protein and amino acid synthesis, and is an important precursor for renal ammoniagenesis as well as for lipid ${ }^{9}$, nucleotide, and alanine synthesis. ${ }^{2,6}$ Glutamine, when introduced into portal hepatic circulation, is used as a substrate for ureagenesis and glucogenesis. ${ }^{5,8}$

Beneficial effects of exogenous glutamine have been observed in patients in catabolic conditions, including surgical stress, sepsis, ${ }^{13}$ bone marrow transplants, ${ }^{10}$ immune suppressor treatments, and burnings; ${ }^{2}$ these effects include the preservation of the mucosal integrity and the prevention of translocation of bacteria and toxins. ${ }^{10}$

The mechanisms and mediators of intestinal adaptation are multifactorial. Among them, luminal nutrition ${ }^{11,14,15}$, pancreaticobiliary secretion, various hormones, ${ }^{15}$ and growth factors ${ }^{16}$ play important roles.

Patients with SBS can cease needing parenteral nutrition through compensatory mechanisms that can last up to 2 years. ${ }^{17}$ Various hormones, such as growth hormone, ${ }^{17}$ glucagon-like peptide $2,{ }^{18}$ and epidermal growth factor, have been used to improve intestinal trophism in SBS. ${ }^{9}$ Glutamine supplementation has been used in clinical and experimental situations of trophic reduction and intestinal absorption damage, although its real efficiency has not yet been proved..$^{20-22}$ When associated with growth hormone, glutamine supplementation has been shown to have a gut-trophic effect and to enhance intestinal absorption, both experimentally $y^{4,22}$ and in clinical studies. ${ }^{17}$ However, other researchers have not found considerable improvement with the association of glutamine and growth hormone. ${ }^{10,23}$

The main purpose of this study was to compare the morphometry of the mucosa of the intestinal remnant of rats undergoing extensive intestinal resection and fed with diets with and without glutamine. Because of the associated weight loss that intestinal resection causes, the influence of different diets on the weight of the animals was also analyzed.

\section{OBJECTIVES}

1) To evaluate the influence of a glutamine-enriched diet on the morphometry of the mucosa of remnant intestines of rats undergoing massive intestinal resection.

2) To analyze the effect of a glutamine-enriched diet on weight loss in these animals after resection.

\section{MATERIALS AND METHODS}

Twenty-five Wistar adult male rats (Rattus norvegicus albinus) that were 6 months old, with weights ranging from 296 to $450 \mathrm{~g}$ (average, $341.9 \mathrm{~g}$ ) were used in the study. All animals underwent a 3-day adaptation period, including being accommodated in appropriate cages.

After a 12-hour night fast, all animals were weighed (initial weight) and anaesthetized with hydrochloride ketamine (Ketalar $\left.{ }^{\circledR}\right)$, IP, $0.2 \mathrm{~mL} / 100 \mathrm{~g}$, for the massive intestinal resection. After the surgery, the weight of the resected bowel was subtracted from the initial weight producing the weight after surgery (real initial weight).

Surgical technique. The abdomen was opened by medial incision. The surgical procedure consisted of partial resection of jejunum and the entire ileum including the ileocecal valve and $1 \mathrm{~cm}$ of the proximal colon, conserving $25 \mathrm{~cm}$ of proximal jejunum in all preparations. The resulting stomas were closed with continuous suturing with 60 monofilament nylon. Then jejunumcolon anastomosis was accomplished lateral-laterally with a length of $1 \mathrm{~cm}$, with continuous suturing with 6-0 monofilament nylon. After surgery, the animals (separated by transparent partition walls) were kept in cages with the capacity for 5 animals and were provided water and food ad libitum.

Diets. The diet without glutamine was composed of soy oil (16.5 g), maize starch $(162.5 \mathrm{~g})$ and calcium caseinate $(55.5 \mathrm{~g})$. The glutamine-enriched diet (12\%) contained soy oil (16.5 g), maize starch (162.5 g), calcium caseinate ( $28 \mathrm{~g})$, and glutamine $(25 \mathrm{~g})$. These diets contained equal numbers of calories and grams of protein, with approximately 994.4 calories, supplying 4.36 calories per gram. The grams of amino acids in the diets with and without glutamine in $50 \mathrm{~g}$ of protein are listed in Table 1. The Nuvilab ${ }^{\circledast}$ ration consisted of amino acids, vitamins (A, D3, K3, B1, B2, B6, $\mathrm{B} 12$, niacin, pantothenic acid, folic acid, biotin, and choline), and minerals (iron, zinc, manganese, selenium, and cobalt).

The animals were randomly divided into 3 groups as follows:

EwG Group (enterectomized / without glutamine)—Comprised 10 animals that underwent intestinal resection and that received the test oral diet without glutamine.

EG Group (enterectomized / with glutamine)-Comprised 10 animals that underwent intestinal resection and that received the test oral diet with glutamine.

ER Group (enterectomized / ration)-Comprised 5 animals undergoing intestinal resection and that re- 
Table 1 - Amino acid content of the diets with and without glutamine in $50 \mathrm{~g}$ of protein.

\begin{tabular}{lcc}
\hline Amino acid & Diet without glutamine & Diet with glutamine \\
\hline aspartic acid & 3.33 & 1.66 \\
glutamic acid & 10.67 & 5.33 \\
Alanine & 1.45 & 0.72 \\
arginine & 1.70 & 0.85 \\
cysteine & 0.13 & 0.06 \\
phenylalanine & 2.39 & 1.19 \\
Glycine & 0.85 & 0.43 \\
histidine & 1.36 & 0.68 \\
isoleucine & 2.43 & 1.21 \\
leucine & 4.48 & 2.24 \\
methionine & 1.41 & 0.70 \\
proline & 4.26 & 2.13 \\
serine & 2.81 & 1.41 \\
tyrosine & 2.60 & 1.30 \\
threonine & 2.09 & 1.04 \\
tryptophan & 0.59 & 0.30 \\
valine & 3.07 & 1.53 \\
glutamine & - & 25 \\
\hline
\end{tabular}

ceived the conventional oral diet (Nuvilab® ration).

The animals were observed for 20 days, were weighed (final weight), and were then killed by sulphuric ether inhalation; The abdomen was reopened, and the stomach, duodenum, remnant jejunum, colon, and liver were removed. After being washed with saline solution $0.9 \%$, the excised tissues were stored in buffered $10 \%$ formol solution for 3 days. Two longitudinal duodenum fragments of $1 \mathrm{~cm}$ were isolated 2 to $4 \mathrm{~cm}$ from the pylorus as well as another from the jejunum 2 to 10 $\mathrm{cm}$ from the anastomosis, encompassing the entire thickness of the small bowel wall. The material was sliced into $5 \mathrm{~m}$ sections, which were stained with hematoxylin and eosin.

For the morphometric study of intestinal mucosa, Kontron Imaging System software was used (Kontron Image Analysis KS 300 program of Kontron Elektronik Gmbh, Image Analysis Division) in conjunction with a Zeiss microscope fitted with a video camera. The video camera transferred the image from the microscope to the computer screen.

The height of each villus was manually delimited with a computer mouse from its apex to the transition into the crypt zone (Figure 1). The studied intestinal mucosa area comprised the entire mucosal thickness from the apex of the villus to the muscularis mucosae (Figure 2). The measurements were expressed in microns. The analysis was made under 100x magnification using specimens in which the villi and the crypts were perpendicular to the muscularis mucosae.
The following measurements were obtained:

- Villus height - from the top of the villus to the villus-crypt junction (Fig. 1).

- Total mucosal thickness - from the top of the villus to the border over the muscularis mисоsae

- Crypt depth - represented by the difference between the total mucosal thickness and the villus height.

\section{Statistical Analysis}

For the analysis of the different values related to postsurgical weight loss and to the measurements of villi height, crypt depth, and total mucosal thickness of the different groups, the nonparametric Kruskal-Wallis test for independent samples was used. For the multiple comparisons, the Dunn test was used. A significance level of 5\% $(P=.05)$ was set.

\section{RESULTS}

The glutamine-enriched diet did not affect the weight evolution of the

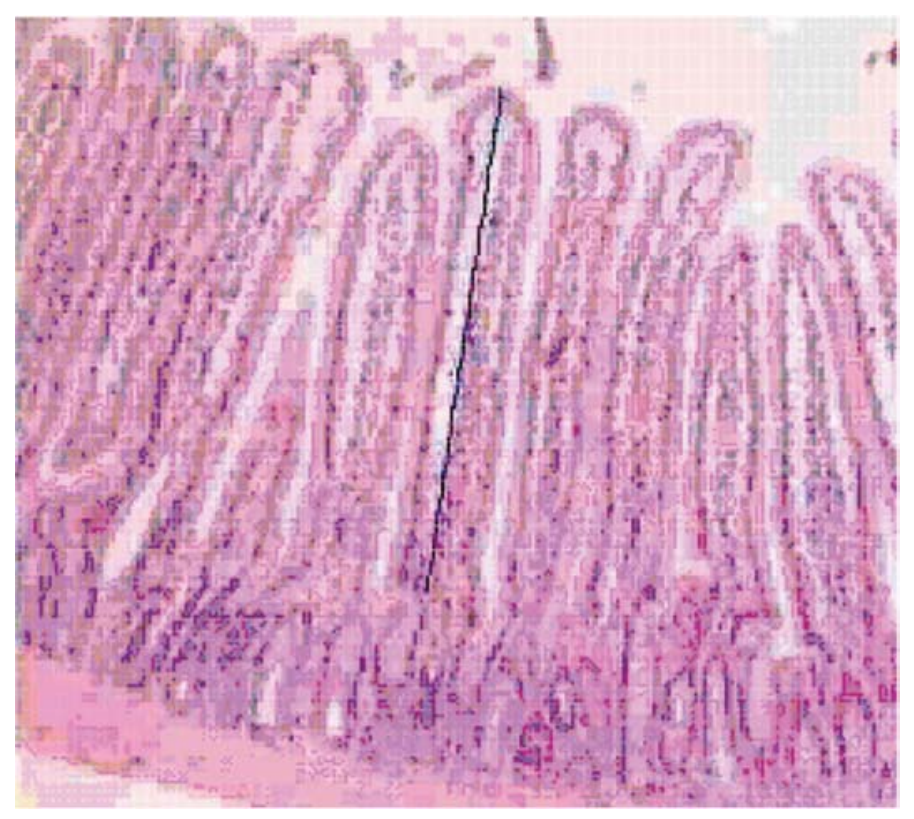

Figure 1 - Histology of a remnant jejunum, depicting the villus height measurement. 
animals. No difference between the real initial weight and the final weight among the animals of the different groups was observed (Table 2).

The results of the morphometric study comparing the duodenal and jejunal mucosa villi height, crypt depth, and total mucosal thickness, of the EwG, EG, and ER groups are shown in Table 3. There was a statistically significant difference $(P<.05)$ in duodenal villi height, jejunal villi height, jejunal crypt depth, and jejunal mucosa thickness (Kruskal-Wallis test). No difference between groups was found for duodenal crypt depth and duodenal mucosa thickness.

Applying the Dunn test to each of the variables that were significantly different, the following was observed: 1) the group that received the glutamine-enriched diet (EG) had duodenal villi that were considerably taller than the EwG group $(P<.05)$ but were similar to the ER group; 2$)$ the EG group had significantly taller jejunal villi, increased jejunal crypt

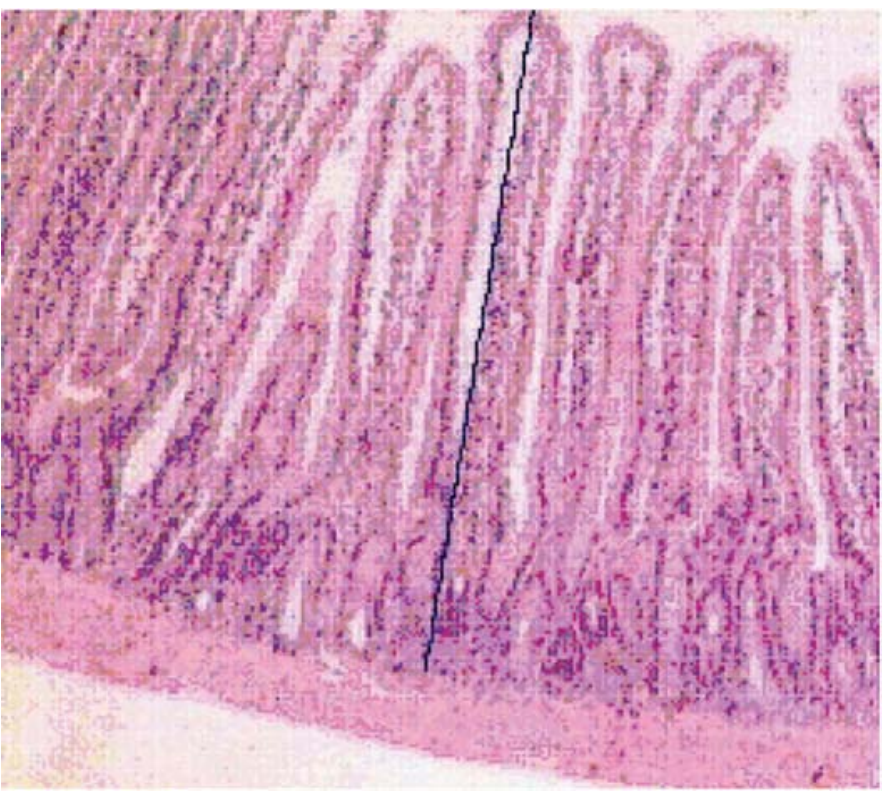

Figure 2 - Histology of a remnant jejunum depicting the total mucosal thickness measurement.

Table 2 - Differences between the real initial and final weight loss expressed.

\begin{tabular}{lrcc}
\hline & $\mathrm{N}$ & Average(grams) & Standard deviation \\
\hline Enteral diet without glutamine & 10 & 157.60 & 17.77 \\
Enteral diet with glutamine & 10 & 155.70 & 31.97 \\
Regular enteral diet & 5 & 121.80 & 26.72 \\
\hline
\end{tabular}

$P>.05$

Table 3 - Enteral diet without glutamine (EwG), enteral diet with glutamine (EG), and regular enteral diet (ER) group comparisons.

\begin{tabular}{|c|c|c|c|c|c|c|c|c|}
\hline Variable & Group & $\mathrm{n}$ & $\begin{array}{l}\text { Average } \\
\text { (microns) }\end{array}$ & $\begin{array}{l}\text { Standard } \\
\text { deviation }\end{array}$ & Median & Minimum & Maximum & $P$ \\
\hline \multirow[t]{3}{*}{ Duodenal villi height } & EwG & 10 & 528.7 & 55.2 & 518.2 & 442.1 & 608.9 & \multirow{3}{*}{$P<.05$} \\
\hline & EG & 10 & 613.5 & 92.3 & 612.3 & 469.3 & 763.6 & \\
\hline & ER & 5 & 659.8 & 83.1 & 656.2 & 556.1 & 782.7 & \\
\hline \multirow[t]{3}{*}{ Duodenal crypt depth } & EwG & 10 & 176.0 & 34.3 & 174.1 & 123.7 & 218.5 & \multirow{3}{*}{$P<.05$} \\
\hline & EG & 10 & 198.1 & 49.2 & 186.7 & 114.8 & 289.0 & \\
\hline & ER & 5 & 174.6 & 38.4 & 180.2 & 134.8 & 231.6 & \\
\hline \multirow[t]{3}{*}{ Duodenal mucosa thickness } & EwG & 10 & 704.7 & 80.8 & 706.1 & 570.0 & 826.7 & \multirow{3}{*}{$P<.05$} \\
\hline & EG & 10 & 811.6 & 119.6 & 822.9 & 635.4 & 971.2 & \\
\hline & ER & 5 & 834.4 & 107.4 & 803.6 & 690.9 & 966.0 & \\
\hline \multirow[t]{3}{*}{ Jejunal villi height } & EwG & 10 & 465.9 & 79.7 & 476.6 & 363.1 & 568.2 & \multirow{3}{*}{$P<.05$} \\
\hline & EG & 10 & 641.8 & 112.4 & 651.5 & 361.7 & 778.8 & \\
\hline & ER & 5 & 620.8 & 138.3 & 622.3 & 477.8 & 798.3 & \\
\hline \multirow[t]{3}{*}{ Jejunal crypt depth } & EwG & 10 & 154.3 & 47.9 & 144.4 & 97.2 & 239.1 & \multirow{3}{*}{$P<.05$} \\
\hline & EG & 10 & 211.5 & 57.5 & 206.6 & 148.0 & 345.1 & \\
\hline & ER & 5 & 170.8 & 47.1 & 159.6 & 124.4 & 222.9 & \\
\hline \multirow[t]{3}{*}{ Jejunal mucosa thickness } & EwG & 10 & 620.2 & 123.1 & 631.6 & 475.2 & 807.3 & \multirow{3}{*}{$P<.05$} \\
\hline & EG & 10 & 853.2 & 140.7 & 871.5 & 510.9 & 981.6 & \\
\hline & ER & 5 & 791.7 & 184.0 & 781.9 & 602.2 & 1016.0 & \\
\hline
\end{tabular}


depth, and thicker jejunal mucosa when compared to the EwG group ( $P$ $<.05)$, but did not differ significantly from the ER group.

\section{DISCUSSION}

Adaptation by and prognosis for SBS patients depend on many factors including patient age, extent and height of the resected segment, presence of the ileocecal valve, presence of the colon, and concomitant intestinal diseases. ${ }^{24}$ Proximal small bowel resection does not lead to large absorption changes, due to the absorption capacity of the ileum, ${ }^{25}$ but it diminishes the secretion of intestinal hormones, such as cholecystokinin and the secretin. ${ }^{26}$ However, extirpation of the ileum causes steatorrhea, due to reduction in the pool of bile salts causing incomplete fat digestion, and diarrhea, because of the cathartic effect of the bile salts that are not absorbed in the colonic mucosa. The presence or absence of the ileocecal valve contributes decisively to the intestinal transit velocity. Its absence is related to an increased velocity, in addition to allowing bacterial colonization of the small bowel, worsening the diarrheic condition..$^{25,27}$

In response to massive intestinal resection, the remaining bowel develops significant adaptation mechanisms to compensate the loss of mucosal surface. Increases of caliber and thickness of the intestinal wall and of absorption and digestion capacity have been observed. The compensatory mechanisms are more intense in the ileum than in the jejunum and reach their development limit 4 weeks after intestinal resection. ${ }^{16}$

This adaptation phenomenon occurs following intestinal resection when nutrients are given orally, consequently improving nutrient absorption, diminishing diarrhea, and even reducing bacterial translocation. Adaptation has been shown to be enhanced by proper nutritional orientation, use of growth hormone, glucagon-like hormone infusion, diets rich in fiber, and glutamine (administered both orally and parenterally), and other measures. ${ }^{17,18,22,28}$

Supplemental glutamine usage has been shown to have trophic benefits for the intestinal mucosa in different clinical and experimental situations, which prompted its study in SBS. $7,28,29,30$

Yang et al. (2000), after administering $2 \mathrm{~g} / \mathrm{kg} /$ day of glutamine by enteral bolus to rats undergoing extensive intestinal resection, did not observe improvement in intestinal adaptation after the 10th day post surgery. ${ }^{31}$

Regarding the toxic effect of cyclosporin on the intestinal epithelium, Zhang et al. (1995) studied rats undergoing small bowel transplant while using immunosuppression with cyclosporin $(15 \mathrm{mg} / \mathrm{kg})$. Animals received either elemental diet with $2 \%$ glutamine or the same diet with balanced nonessential amino acids (without glutamine). They observed reduction of bacterial translocation and increased crypt depth and villi height of the transplanted intestine in the groups that had the glutamine-enriched diet. ${ }^{28}$

The study of malnourished rats by Tannuri et al. (2000) found that the use of oral diet supplemented with $2 \%$ glutamine was significantly more efficient in correcting the alterations of the jejunal crypts than the control regular diet, and the former also improved trophism of intestinal mucosa. $^{30}$

Many experimental ${ }^{4,22}$ and clini$\mathrm{cal}^{32}$ studies have found beneficial effects in SBS when growth hormone was associated with glutamine, showing it improved the absorption and capacity for adaptation of the remnant intestine.

An experimental protocol with rats undergoing $85 \%$ resection of the small bowel showed that animals receiving a glutamine enriched diet and exogenous growth hormone had taller intestinal villi and thicker mucosae, compared to those treated with either in isolation. In fact, the glutamine enriched diet, per se, was not different from controls receiving isocaloric isonitrogenous diets, minus glutamine. ${ }^{22}$ Thse data confirm a previous similar report. ${ }^{27}$

Byrne et al. (1995) studied the effect of a carbohydrate-rich, low-fat diet supplemented with glutamine and growth hormone for 28 days followed by supplementation with glutamine alone in 47 adults with SBS. The patients in this study had an average jejunal-ileal length of $50 \mathrm{~cm}$ and had been dependent on parenteral nutrition 5 to 7 years. ${ }^{17}$ Isolated measures promoted subtle improvement of intestinal absorption, however, when growth hormone and glutamine were used together, protein absorption increased $38 \%(P<.02)$ and the fecal volume was reduced by one-third $(P<.05)$. Four weeks later, all patients had gained weight, increased enteral nutrition, and reduced intravenous liquids and calories; $57 \%$ of patients ceased needing parenteral nutrition while $30 \%$ reduced the need for parenteral nutrition. Is was concluded that the intestinal function of patients with SBS for a long period of time can improve with a carbohydrate-rich, low-fat diet supplemented with growth hormone and glutamine. ${ }^{17}$

However, other researchers observed no such improvement of the fatty acid absorption or weight gain when growth hormone and glutamine were included in the SBS treatment. ${ }^{18}$ Similarly, an oral diet with glutamine, low in fat, and rich in carbohydrates did not positively affect intestinal morphology, gastrointestinal transit, Dxylose absorption, or loss of moist weight of the feces in patients with SBS. ${ }^{21}$ 
Szkudlarek et al. (2000), in a double-blind crossover study, analyzed the effect of a high dose of growth hormone associated with glutamine, administered for 28 days, in 8 patients with SBS. At the end of the treatment, improvement of absorption of carbohydrates, fat, and nitrogen was not observed. ${ }^{23}$

The enterectomized animals in this study that received the glutamine-enriched diet (EG group) had taller jejunal villi, deeper jejunal crypts, and thicker jejunal mucosa compared to the group that received the diet without glutamine. However, the results for the EG group were similar to those obtained in the animals that received usual ration. It is possible that animals given the glutamine-enriched diet, which was isonitrogenous with the control diet, became protein deficient in comparison to those receiving the usual ration. To avoid this, most authors recommend adding glutamine to the study group diet and a nonimmuno-stimulating amino acid, such as glycine, to the control group diet. Finally, enterectomized rats that received a glutamine-enriched diet presented a better adaptation of the intestinal mucosa when compared to the enterectomized rats that received the same diet without glutamine.

\section{CONCLUSIONS}

In rats with experimentally pro- duced short-bowel syndrome, glutamine-enrichment of an isonitrogenous test diet was associated with an improved adaptation response by the intestinal mucosa but not reduced weight loss. However, the adaptation response in the group receiving the glutamine-enriched diet was not improved over that for the group fed regular chow.

\section{ACKNOWLEDGMENTS}

Professor Francis dos Reis Patrício, of the Pathological Anatomy Discipline of UNIFESP and Mr. Edson Pereira Silva, laboratory staff of FMUSP.

\section{RESUMO}

RIBEIRO SR e col. Perda de peso e estudo morfométrico da mucosa intestinal de ratos submetidos à ressecção subtotal de intestino delgado. Influência do uso de dieta com glutamina. Rev. Hosp. Clín. Fac. Med. S. Paulo 59(6):349-356, 2004.

A síndrome do intestino curto é responsável por alterações metabólicas que comprometem o estado nutricional do paciente. A glutamina é nutriente essencial para os enterócitos.

OBJETIVOS: Estudou-se o efeito da administração de dieta com glutamina, em ratos submetidos à ressecção subtotal do intestino delgado, avaliando a perda de peso pós-operatória e a morfometria da mucosa intestinal.

MÉTODOS: Foram constituídos três grupos de ratos Wistar machos recebendo as seguintes dietas: com glutamina (grupo EG), sem glutamina (grupo EsG), e a dieta padrão do labo- ratório (grupo ER). A ressecção intestinal foi realizada em todos os animais incluindo-se a válvula íleo-cecal, com remanescente jejunal de apenas $25 \mathrm{~cm}$ a partir do piloro, anastomosado látero-lateralmente ao cólon ascendente. A diferença entre o peso inicial real e ao final do experimento no $20^{\circ}$ dia pós-operatório foi registrada antes do sacrifício. Fragmentos de mucosa do duodeno e jejuno foram colhidos e corados com hematoxilina-eosina. Realizou-se o estudo morfométrico da mucosa intestinal, por meio de sistema digital associado ao microscópio ótico. Mediu-se a altura das vilosidades, a profundidade das criptas e a extensão total da mucosa intestinal.

RESULTADOS: A perda de peso entre os três grupos não diferiu estatisticamente. A análise da morfometria da mucosa intestinal mostrou diferença significativa: 1) animais do grupo Enterectomia com Glutamina (EG) apresentaram vilosidade duodenal sig- nificativamente maior que o grupo EsG $(p<0,05)$, mas não diferiram do grupo que recebeu dieta padrão do laboratório (ER); 2) nas medidas da vilosidade jejunal, cripta jejunal e mucosa jejunal, o grupo Enterectomia com Glutamina (EG) apresentaram maior altura, profundidade e extensão, respectivamente, em relação ao grupo Enterectomia sem glutamina (EsG) $(\mathrm{p}<0,05)$, porém não diferiu estatisticamente do grupo dieta padrão do laboratório (ER).

CONCLUSÕES: A oferta de dieta oral acrescida de glutamina não contribui para reduzir a perda de peso dos animais submetidos à ressecção intestinal extensa, em comparação a dieta padrão, mas apresentou melhor efeito na adaptação intestinal.

\section{UNITERMOS: Glutamina. Síndro- me do Intestino Curto. Mucosa intes- tinal.}




\section{REFERENCES}

1. Rasslan S, Quintão REC, Scalissi MN, Bianco AC, Chaves AF, Goldberg AC, et al. Alterações dos Lípides Séricos e Hepáticos após Ressecções Intestinais Extensas no Rato. Rev Ass Med Brasil 1985;31(7):111-5.

2. Colomb V, Darcy VB, Jobert A, Guihot G, Morel MT, Corriol O, et al. Parenteral nutrition modifies glucose and glutamine metabolism in rat isolated enterocytes. Gastroenterology 1997;112(2):429-36.

3. Saad JR, Bianco AC, Minas MR, Chazanas JC, Oliveira AM, Hell $\mathrm{SN}$, et al. Alterações Metabólicas em Ratos Submetidos a Ressecção Intestinal Extensa ou Derivação Jejunoileal. Rev Paul Med 1985;103(4):171-5.

4. Waitzberg DL, Cukier C, Mucerino DR, Logulo AF, Torrinhas RSM, Castro I. Small bowel adaptation with growth hormone and glutamine after massive resection of rat's small bowel. Nutr Hosp 1999;14(2):81-90.

5. Stumvoll M, Perriello G, Meyer C, Gerich J. Role of glutamine in human carbohydrate metabolism in kidney and other tissues. Kidney Int 1999;55(3):778-92.

6. Smith RJ. Glutamine metabolism and its physiologic importance. J Parenter Enteral Nutr 1990;14(4 Suppl):40S-44S.

7. Souba WW, Herskowitz K, Salloum RM, Chen MK, Austgen TR. Gut glutamine metabolism. J Parenter Enteral Nutr 1990;14(4 Suppl):45S-50S

8. Klimberg VS, Souba WW, Salloum RM, Holley DT, Hautamaki $\mathrm{RD}$, Dolson DJ, et al. Intestinal glutamine metabolism after massive small bowel resection. Am J Surg 1990;159(1):2732 .

9. Ko TC, Beauchamp D, Townsend CMJ, Thompson JC. Glutamine is essential for epidermal growth factor-stimulated intestinal cell proliferation. Surgery 1993;114(2):147-53.

10. Scolapio JS, Camilleri M, Fleming R, Oenning L.V, Burton D, Sebo T, et al. Effect of growth hormone, glutamine, and diet on adaptation in short-bowel syndrome: a randomized, controlled study. Gastroenterology 1997;113(4):1074-81.

11. Wiren M, Adrian TE, Arnelo U, Permert J, Staab P, Larsson J. Early gastrointestinal regulatory peptide response to intestinal resection in the rat is stimulated by enteral glutamine. Dig Surg 1999;16(3):197-203.

12. Shanbhogue LK, Molenaar JC. Short-bowel syndrome: metabolic and surgical management. Brit J Surg 1994;81(4):486-99.

13. Noguchi Y, James H, Fischer JE, Hasselgren P. Increased glutamine consumption in small intestine epithelial cells during sepsis in rats. The Am J Surg 1997;173(3):199-205.

14. Feldman EJ, Dowling RH, Naughtonj MC, Peters TJ. Effects of oral versus intravenous nutrition on intestinal adaptation after small bowel resection in the dog. Gastroenterology 1976;70(5 PT.1):712-9.

15. Jekins AP, Thompson RP. Mechanisms of small intestinal adaptation. Dig Dis 1994;12(1):15-27.
16. Helmrath MA, Vanderkolk WE, Can G, Erwin CR, Warner BW. Intestinal adaptation following massive small bowel resection in the mouse. J Am Coll Surg 1996;183(5):441-9.

17. Byrne TA, Persinger RL, Young LS, Ziegler TR, Wilmore DW. A new treatment for patients with short-bowel syndrome. Growth hormone, glutamine, and a modified diet. Ann Surg $1995 ; 222(3): 243-54$

18. Jeppesen PB, Hartmann B, Thulesen J, Graff J, Lohmann J, Hansen BS, et al. Glucagon-like peptide 2 improves nutrient absorption and nutritional status in short-bowel patients with no colon. Gastroenterology 2001;120(4):806- 15 .

19. Juno RJ, Williams JL, Knott AW, Erwin CR, O'brien DP, Warner BW. A serum factor after intestinal resection stimulates epidermal growth factor signaling and proliferation in intestinal epithelial cells. Surgery 2002;132(2):377-83.

20. Neves JS, Aguilar-Nascimento E, Silva MHGG, Bicudo AS, Nascimento M, Nochi R Jr. Influência da glutamina na mucosa do intestino delgado de ratos submetidos a enterectomia extensa. Rev Col Bras Cir 2003;30(6):406-15.

21. Scolapio JS, McGreevy K, Tennyson GS, Burnett OL. Effect of glutamine in short-bowel syndrome. Clin Nutr 2001;20(4):31923.

22. Zhou X, Li YX, Li N, Li JS. Glutamine enhances the gut-trophic effect of growth hormone in rat after massive small bowel resection. J Surg Res 2001;99(1):47-52.

23. Szkudlarek J, Jeppesen PB, Mortensen PB. Effect of high dose growth hormone with glutamine and no change in diet on intestinal absorption in short bowel patients: a randomized, double blind, crossover, placebo controlled study. Gut 2000;47(2):199-205.

24. Thompson JS, Langnas NA, Pinch LW, Kaufman S, Quigley EMM, Vanderhoof JA. Surgical approach to short bowel syndrome. experience in a population of 160 patients. Ann Surg 1995;222(4):600-5.

25. Dudrick SJ, Latifi R, Fosnocht DE. Management of the short bowel syndrome. Surg Clin North Am 1991;71(3):625-43.

26. Rombeau JL, Rolandelli RH. Enteral and parenteral nutrition in patients with enteric fistulas and short bowel syndrome. Surg Clin North Am 1987;67(3):551-71.

27. Vanderhoof JA Langnas AN. Short-bowel syndrome in children and adults. Gastroenterology 1997;113(5):1767-78.

28. Zhang W, Frankel WL, Bain A, Choi D, Klurfeld DM, Rombeau JL. Glutamine reduces bacterial translocation after small bowel transplantation in cyclosporine-treated rats. J Surg Res $1995 ; 58(2): 159-64$

29. Gianotti L, Alexander JW, Gennari R, Pyles T, Babcock GF. Oral glutamine decreases bacterial translocation and improves survival in experimental gut-origin sepsis. J Parenter Enteral Nutr 1995;19(1):69-74 
30. Tannuri Uenis, Carraza FR, Iriya K. The effects of glutaminesupplemented diet on the intestinal mucosa of the malnourished growing rat. Rev Hosp Clin Fac Med S. Paulo 2000;55(3):8792.

31. Yang H, Larsson J, Permert J, Braaf Y, Wiren M. No effect of bolus glutamine supplementation on the post resectional adaptation of small bowel mucosa in rats receiving chow ad libitum. Dig Surg 2000;17(3):256-60.
32. Inoue I, Copeland EM, Souba WW. Growth hormone enhances amino acid uptake by the human small intestine. Ann Surg 1994;219(6):715-24. 